\title{
Generation and evaluation of IgY-scFv based mimetics against canine parvovirus
}

\author{
Shikun Ge ${ }^{1,2}$, Xingxing Zhang ${ }^{4}$, Fagang Zhong ${ }^{4}$, Xiang Liu ${ }^{1}$ and Xiaoying Zhang ${ }^{1,2,3,4^{*}}$ (D)
}

\begin{abstract}
Antibody mimetics may be used for various biomedical applications, especially those for which conventional antibodies are ineffective. In this study, we developed a smaller molecular chicken IgY mimetic peptide (IgY-peptide) based on the complementarity-determining regions (CDRs) of the anti-canine parvovirus (CPV) IgY-scFv prepared previously. The mimetic peptide showed no cross-reactivity with canine distemper virus (CDV) and canine coronavirus (CCV) and showed excellent protective properties for Crandell-Rees Feline Kidney (CRFK) cells against CPV. This study is the first attempt to develop a mimetic lgY-peptide and demonstrates the ease and feasibility in generating such a novel antibody-like functional molecule for biomedical purposes.
\end{abstract}

Keywords: Antibody mimetics, lgY-peptide, Canine parvovirus (CPV), IgY-scFv, IgY technology

\section{Introduction, methods and results}

Numerous attempts have been successfully made to generate avian sourced monoclonal IgY (mIgY) or recombinant functional IgY fragments, particularly the single chain fragment variables (scFv) [1,2], for immunological detection [3], diagnostic and therapeutic purposes [4] in veterinary and human medicine.

In our recent study [4], hens were immunized with virus-like particles (VLP) of canine parvovirus VP2 (CPV-VP2) and the specific IgY-scFv were generated by using the T7 phage display system. This result confirmed the feasibility of generating diversified avian IgY-scFv libraries against pathogenic targets of interest for both diagnostic and therapeutic purposes. However, $\mathrm{scFv}$ is still relatively large in molecular weight, complex in the states of spatial structure and charge, and easy to form aggregations, however, such limits could be overcome by designing antibody like small molecules, the antibody

\footnotetext{
*Correspondence: zhang@bio.uminho.pt

${ }^{1}$ Chinese-German Joint Laboratory for Natural Product Research, Key Laboratory of Biological Resources and Ecological Environment of Qinba Areas, School of Biological Science and Engineering, Shaanxi University of Technology, Hanzhong, China

Full list of author information is available at the end of the article
}

mimetic peptide, which retains the characteristics of the specific antibody to the maximal extent, while referenced the advantages and convenience of peptides [5].

After polyclonal antibodies, full-length monoclonal antibodies and recombinant antibody fragments, antibody-based mimetics (peptides) have been considered as the fourth generation of antibody engineering, enabling the optimized and easy design of target molecules of interest, easy production of large amount of mimetics based on peptide design and synthesis, higher molecular stability for better biomedical applications, and an alternative to animal-based antibody generation strategies [5]. The current study aimed to generate anti-CPV VP2 IgY-scFv based mimetics and to evaluate the feasibility of such mimetics as a specific antibody-like functional molecule.

This study builds on our findings previously published [4], CDR and framework region sequences of our previously obtained IgY-scFv against the VLP of CPV-VP2 (Figure 1A) [4] were used to create an antibody mimetic peptide comprising two interacting $\mathrm{V}_{\mathrm{H}-}$ (VHCDR1) and $\mathrm{V}_{\mathrm{L}-}$ (VLCDR3) derived CDRs (31 AA, VHCDR1VHFR2-VLCDR3). The framework region (VHFR2) from either the $\mathrm{V}_{\mathrm{H}}$ or $\mathrm{V}_{\mathrm{L}}$ domain orients the two CDRs in a manner resembling their disposition in native molecules

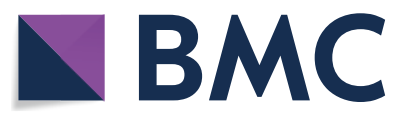

c) The Author(s) 2021. This article is licensed under a Creative Commons Attribution 4.0 International License, which permits use, sharing, adaptation, distribution and reproduction in any medium or format, as long as you give appropriate credit to the original author(s) and the source, provide a link to the Creative Commons licence, and indicate if changes were made. The images or other third party material in this article are included in the article's Creative Commons licence, unless indicated otherwise in a credit line to the material. If material is not included in the article's Creative Commons licence and your intended use is not permitted by statutory regulation or exceeds the permitted use, you will need to obtain permission directly from the copyright holder. To view a copy of this licence, visit http://creativeco mmons.org/licenses/by/4.0/. The Creative Commons Public Domain Dedication waiver (http://creativecommons.org/publicdomain/ zero/1.0/) applies to the data made available in this article, unless otherwise stated in a credit line to the data. 
A

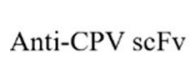

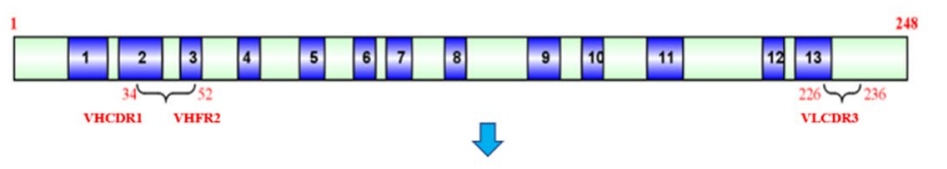

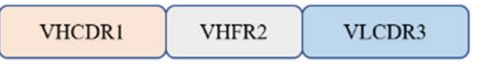

SYCMHWVRQAPGKGLEWVAGSIDSSAGDAAI
B

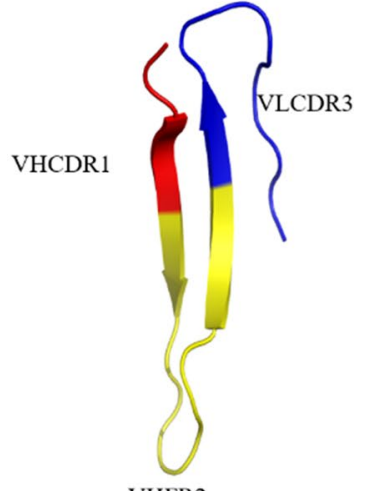

VHFR2

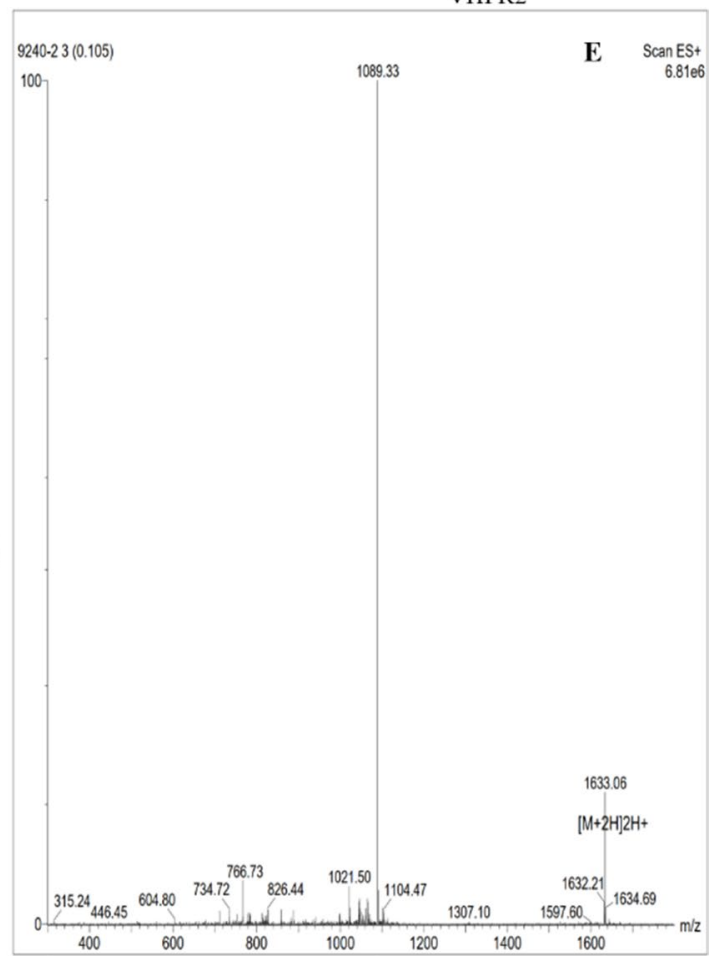

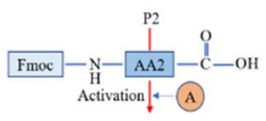<smiles>[CH]1C[Te]C1</smiles>
Fmoc 2 Deblocking

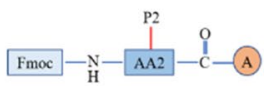

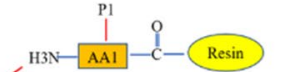

A. Coupling P2

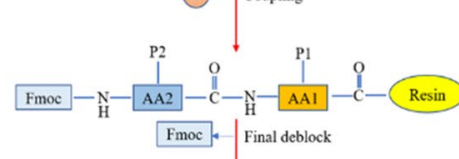

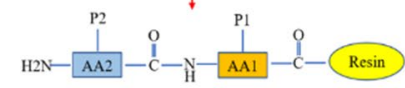

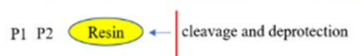
$\mathrm{H}_{2 \mathrm{~N}}-\mathrm{AA}_{\mathrm{A}}-\stackrel{\mathrm{O}}{\mathrm{C}}-\mathrm{N}-\mathrm{N}-\mathrm{AA1}-\stackrel{\mathrm{i}}{\mathrm{C}}-\mathrm{OH}$

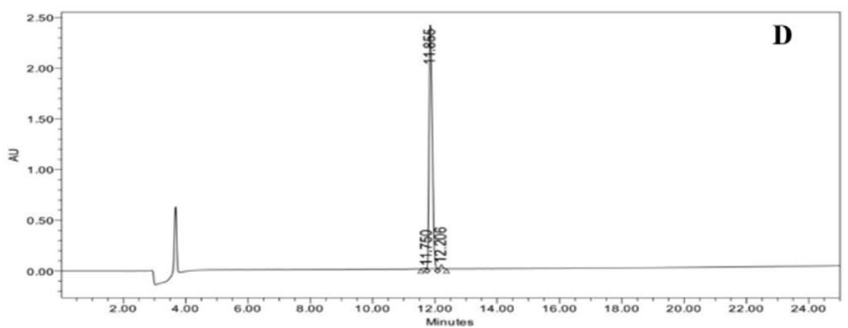

AAl: Amino Acid 1 AA2: Amino Acid 2 Fmoc: Fmoc protecting group A: Activator P1: Side-chain protecting group 1 $\mathrm{P} 2$ : Side-chain protecting group 2

C Repeat steps for each amino
acid addition<smiles>C1CCCCC1</smiles> 
analyzed by mass spectrometry (MS) (Jietide Biotech, Nanjing, China) (Figure 1E).

To evaluate the specificity of IgY-peptide in the detection of CPV, a total of 28 clinical dog stool samples were collected using sterile swabs in an animal hospital (Xinger, Xi'an, China). Among them, there were 24 positive samples and four negative samples (samples number 4, 6, 12 and 26) confirmed by a commercial colloidal gold test strip (ICA). Each sample was homogenized (10\%, $\mathrm{w} / \mathrm{v})$ in PBS $(1 \mathrm{~mL}, \mathrm{pH} 7.2)$ and centrifuged, then the supernatants were analyzed by ELISA and PCR [4]. There was no difference in the detection performance of IgYpeptide and IgY-scFv on CPV clinical fecal samples. The IgY-peptide detection results were positive in some of the samples (samples number 5, 11, 15, 20, 21 and 28), and its detection value was not as high as IgY-scFv (Table 1). The IgY-peptide had no cross-reactivity with $\mathrm{CDV}$ and $\mathrm{CCV}$ (Figure 2A).

Crandell-Rees Feline Kidney (CRFK) cells were trypsinized and plated in a 96-well plate at a density of $5 \times 10^{3}$ cells/well. The cells were grown in Dulbecco's Modified Eagle Medium (DMEM) containing 10\% Fetal Bovine Serum (FBS) overnight at $37{ }^{\circ} \mathrm{C}$ in $5 \% \mathrm{CO}_{2}$ incubator. The cells were treated with increasing mimetic peptide concentrations followed by a cell proliferation assay. The CCK-8 assay kit (Beyotime, Shanghai, China) was used to measure the cell viability in different concentrations of the mimetic peptide. Cells in medium without the IgY-peptide were considered as positive control for the viability assay and monitored at
$24 \mathrm{~h}$. The CCK-8 cell proliferation assay protocol was followed, and the absorbance was recorded at $450 \mathrm{~nm}$ using a microplate reader (Beyotime, Shanghai, China). The IgY-peptide had no toxicity to cells (cell survival rate $>90 \%$ ) (Figure $2 \mathrm{~B}$ ), when its concentrations were below $100 \mu \mathrm{g} / \mathrm{mL}$. We can therefore determine that a concentration $(\leq 100 \mu \mathrm{g} / \mathrm{mL})$ is suitable for subsequent cellular studies.

The ability of the IgY-peptide to inhibit virus growth on the CRFK cells was determined. CRFK cells were grown in six-well microplates $\left(1.5 \times 10^{6}\right.$ cells/well $)$ for $24 \mathrm{~h}$. Cell culture media were removed, and the cells were washed three times with PBS. Then, new media containing virus supernatant mixed with increasing concentrations (10, $20,40,80$ and $100 \mu \mathrm{g} / \mathrm{mL}$ ) of IgY-peptide were separately added into the cells and incubated for $24 \mathrm{~h}$ at $37^{\circ} \mathrm{C}$. The CCK-8 cell proliferation assay protocol was followed, and the absorbance was recorded at $450 \mathrm{~nm}$ using a microplate reader (Beyotime, Shanghai, China). Cells (BC) became significantly rounded, broke away from the bottom, and broke apart into fragments. With the increasing mimetic peptide concentration, the cells state was significantly improved, and most of the cells showed shuttle shape when the concentration of IgY-peptide was $100 \mu \mathrm{g} /$ $\mathrm{mL}$ (Figure $2 \mathrm{C}$ ). The cell protection rate showed a IgYpeptide dose-dependent type (Figure 2D).

All experiments were performed with at least three independent experiments. Statistical significance was determined by the Student $t$ test when two groups were compared, or by one-way analysis of variance (ANOVA),

Table 1 Comparison of IgY-scFv and IgY-peptide mimetic detection on clinical samples.

\begin{tabular}{|c|c|c|c|c|c|c|c|c|c|}
\hline Sample & $\operatorname{lgY}-s c F v($ Mean \pm SD) & $\begin{array}{l}\text { IgY-peptide } \\
(\text { Mean } \pm \text { SD) }\end{array}$ & ICA & PCR & Sample & IgY-scFv (Mean \pm SD) & $\begin{array}{l}\text { IgY-peptide } \\
(\text { Mean } \pm \text { SD) }\end{array}$ & ICA & PCR \\
\hline 1 & $0.52 \pm 0.02$ & $0.32 \pm 0.00$ & + & + & 16 & $0.51 \pm 0.01$ & $0.48 \pm 0.12$ & + & + \\
\hline 2 & $0.52 \pm 0.01$ & $0.46 \pm 0.03$ & + & + & 17 & $0.85 \pm 0.03$ & $0.99 \pm 0.17$ & + & + \\
\hline 3 & $0.59 \pm 0.01$ & $0.52 \pm 0.02$ & + & + & 18 & $0.67 \pm 0.01$ & $0.59 \pm 0.13$ & + & + \\
\hline 4 & $0.14 \pm 0.03$ & $0.05 \pm 0.00$ & - & - & 19 & $0.71 \pm 0.01$ & $0.54 \pm 0.16$ & + & + \\
\hline 5 & $1.51 \pm 0.00$ & $0.35 \pm 0.04$ & + & + & 20 & $0.84 \pm 0.05$ & $0.31 \pm 0.05$ & + & + \\
\hline 6 & $0.11 \pm 0.02$ & $0.03 \pm 0.01$ & - & - & 21 & $0.67 \pm 0.01$ & $0.32 \pm 0.04$ & + & + \\
\hline 7 & $1.99 \pm 0.06$ & $1.56 \pm 0.35$ & + & + & 22 & $2.2 \pm 0.13$ & $1.43 \pm 0.27$ & + & + \\
\hline 8 & $0.56 \pm 0.03$ & $0.64 \pm 0.02$ & + & + & 23 & $0.87 \pm 0.01$ & $0.59 \pm 0.18$ & + & + \\
\hline 9 & $0.82 \pm 0.00$ & $0.66 \pm 0.03$ & + & + & 24 & $0.45 \pm 0.01$ & $0.32 \pm 0.02$ & + & + \\
\hline 10 & $1.1 \pm 0.05$ & $0.96 \pm 0.03$ & + & + & 25 & $0.58 \pm 0.00$ & $0.93 \pm 0.03$ & + & + \\
\hline 11 & $1.47 \pm 0.08$ & $0.74 \pm 0.04$ & + & + & 26 & $0.15 \pm 0.02$ & $0.04 \pm 0.00$ & - & - \\
\hline 12 & $0.14 \pm 0.03$ & $0.06 \pm 0.01$ & - & - & 27 & $0.33 \pm 0.00$ & $0.51 \pm 0.19$ & + & + \\
\hline 13 & $0.83 \pm 0.03$ & $0.77 \pm 0.03$ & + & + & 28 & $1.98 \pm 0.01$ & $0.96 \pm 0.03$ & + & + \\
\hline 14 & $0.86 \pm 0.01$ & $0.57 \pm 0.05$ & + & + & $\mathrm{NC}$ & $0.03 \pm 0.02$ & $0.07 \pm 0.01$ & & \\
\hline 15 & $0.84 \pm 0.04$ & $0.22 \pm 0.04$ & + & + & & & & & \\
\hline
\end{tabular}

"+" the ICA positive samples, "-" the ICA negative samples; NC, negative control, the sample was replaced by BSA. Statistical principle, P/N $>2.0$ (P samples value; N NC value), it can be judged as positive at the level of $99.9 \%$. Results are means of three replicates. The PCR and ICA results were in accordance to [4]. 

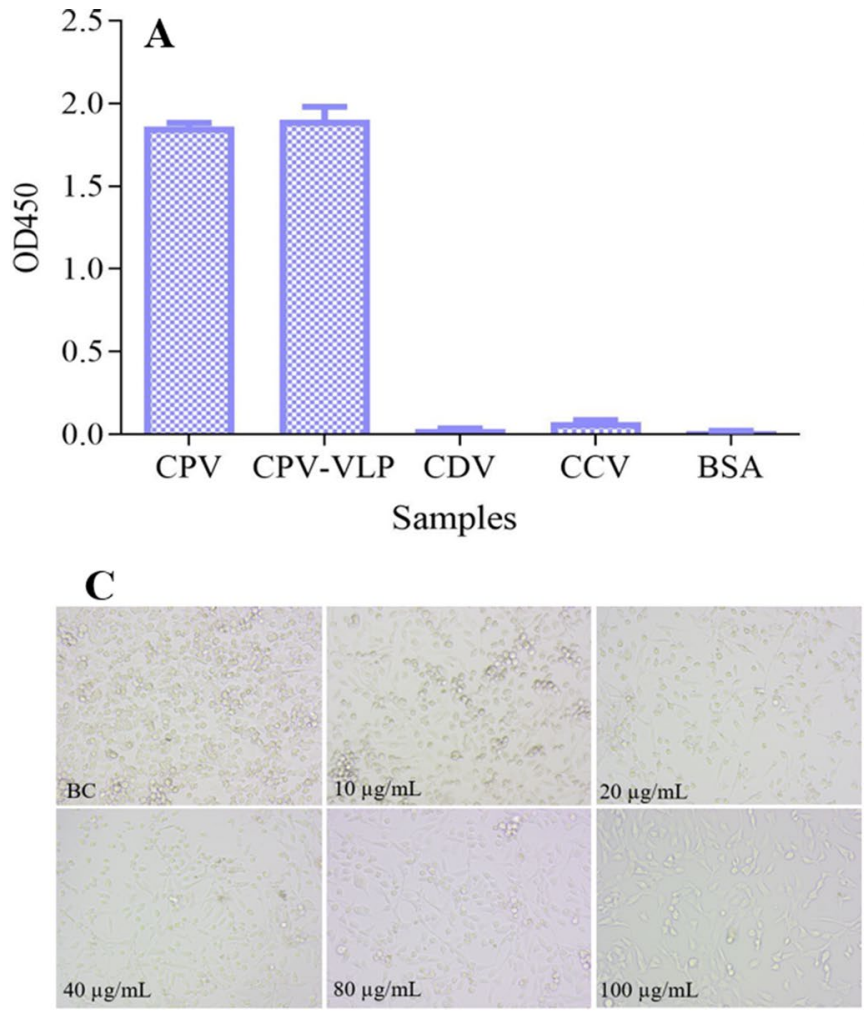

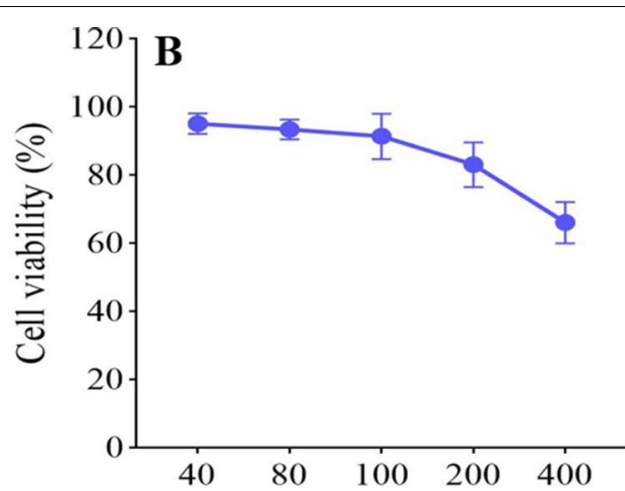

IgY mimetic peptide concentration $(\mu \mathrm{g} / \mathrm{mL})$

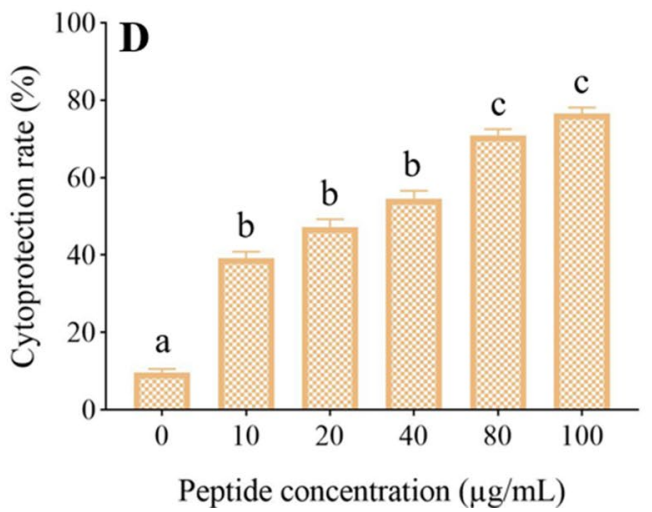

Figure 2 The protective rate of IgY-peptide against CPV-infected cells. A The specificity analysis of mimetic peptide. Control group: bovine serum albumin (BSA). B Cytotoxicity of increasing IgY-peptide concentrations on CRFK cells. C Healthy cells ( $100 \mu \mathrm{g} / \mathrm{mL}$ ): shuttle shape; Cytopathic effect (CPE; BC): cells rounded, detached from bottom and lysed $(400 \times)$. BC, blank control, the peptide replaced by PBS. D Results are means of three replicates (Mean $\pm \mathrm{SD})$, different letters represent significant differences $(p<0.5)$.

when more than two groups were compared. $p<0.05$ was considered to be statistically significant.

\section{Discussion}

Antibodies exhibit versatility and have a broad spectrum of use as powerful tools in research, detection, diagnosis and therapy as they, in theory, can direct to any desired target. Antiserum (IgY from avian egg yolk) based polyclonal antibody, hybridoma technique based full-length monoclonal antibody and genetically engineered antibody fragments and chimeras can be considered as three generations of antibody engineering which exhibit different characteristic, advantages and limits (Table 2), as well as suitable application areas. Antibody mimetics is a promising alternative to animal sourced antibodies which has developed in the last decade arising from advances in protein and peptide design and synthesis, and better understanding of antibody function and structure [5].

The generation of avian sourced monoclonal IgY (mIgY), particularly IgY-scFv, combines the advantages of avian IgY antibodies and features of monoclonal antibodies (mAbs), with validated potential for immunological detection and diagnosis, for screening and validating

Table 2 Antibody generation platforms and their feature.

\begin{tabular}{llllll}
\hline Antibody type & Stability & Specificity & Homogeneity & Reproducibility & Representative technology \\
\hline Polyclonal antibody & +++ & + & + & + & Mammal antiserum, avian IgY technology \\
Monoclonal antibody & ++ & +++ & ++ & ++ & Hybridoma technique \\
Recombinant antibody (fragment) & + & +++ & +++ & +++ & Phage display \\
Antibody mimetics & +++ & ++ & +++ & +++ & Protein direct evolution, CDR-FR fusion \\
\hline
\end{tabular}


biomarkers and for therapeutic uses in both veterinary and human medicine $[1,2]$.

In the current study, we designed the antibody mimetic based on three major antigen-binding entities (VHCDR1, VHFR2 and VLCDR3) that reside in a variable domain of either the heavy chain $\left(\mathrm{V}_{\mathrm{H}}\right)$ or light chain $\left(\mathrm{V}_{\mathrm{L}}\right)$ of the antigen-binding fragment (Fab) of antibody (Figure 1) [5, 6]; despite it is accepted that antigen recognition by whole antibodies requires multiple noncovalent forces involving all six CDR loops residing in the $\mathrm{V}_{\mathrm{H}}$ and $\mathrm{V}_{\mathrm{L}}$ domains, and the contributions of synergic interactions of $\mathrm{V}_{\mathrm{H}}$ and $\mathrm{V}_{\mathrm{L}}$ domains are not well understood [6]. To simplify the peptide design, we designed the IgY-peptide in reference to previous study [6], However, it could be of interest to construct phage display peptide libraries and applied to the epitopes analysis of a specific monoclonal antibody with affinity selection of a peptide-mimetic, to optimize the peptide by screening and selecting antigen-recognition sites in more complete domains based on the entire IgY-scFv sequence. The efficacy of such selected peptide could be further increased and the structure could be optimized, which should be a research direction in the future [7]. Instead we chose a relatively simpler mimetic design by using the following principles: firstly, as antigen recognition by intact $F a b$ is synergistically produced by all six CDRs residing in both the $\mathrm{V}_{\mathrm{H}}$ and $\mathrm{V}_{\mathrm{L}}$ domains, it should contain at least two antigen-binding sites: one from the $V_{H}$ and the other from the $V_{L}$ domain. Such synergistic recognition cannot be accomplished if the CDR loops all originate from one variable domain $[6,8]$. Secondly, as the CDR3 loop is the central of Fab, most accessible antigen binding segment in an intact Fab, it should be regarded as an essential component of the mimetic [9-11]. Thirdly, the CDR3 loop should be complemented by either the CDR1 or CDR2 loop of the other variable domains, as these are normally the closest to CDR3 in the parent antibody. Fourthly, the C-terminus of the selected CDR1 or CDR2 loop and the $N$-terminus of the selected CDR3 loop should be joined with a framework region selected from either the $V_{H}$ or the $V_{L}$ to approximate the linkage of CDR in the parent molecule.

Apart from general advantages of antibody mimetics [5], IgY-peptides may offer additional superiority as specific antibodies against mammalian conserved targets can be better obtained by using IgY technology [1]. A deeper and better understanding of IgY molecule, IgY affinity maturation and IgY glycosylation may be helpful to provide further insights into rational IgY-peptide design.

As a pilot study, we conclude that avian IgY-scFv based mimetics can be designed and generated with confirmed specificity and neutralization ability, which enables diversified antibody engineering and further development of IgY technology.

\section{Abbreviations}

CPV: Canine parvovirus; VLP: Virus-like particles; scFv: Single chain fragment variables; ICA: Immunochromatographic assay; CDV: Canine distemper virus; CCV: Coronavirus; mAbs: Monoclonal antibody; IgY-scFv: Chicken IgY single chain variable fragments; CRFK: Crandell-Rees feline kidney; DMEM: Dulbecco's modified eagle medium; CDRs: Complementarity-determining regions; BSA: Bovine serum albumin; FBS: Fetal bovine serum; mlgY: Monoclonal IgY; MS: Mass spectrometry; HPLC: High performance liquid chromatography.

\section{Acknowledgements}

Dr XY Zhang is grateful for the Distinguished Professorship awarded by Shaanxi University of Technology that provides an excellent environment in which to conduct research. Dr Zhang also thanks the University of Guelph for providing an adjunct faculty position and opportunities for fruitful collaboration.

\section{Authors' contributions}

$X Y Z$, FGZ and SKG conceived this project. SKG, XXZ and XL performed the experiments. XYZ and SKG wrote the manuscript. All authors read and approved the final manuscript.

\section{Funding}

This work was supported by the China Natural Science Foundation (31873006, 31572556) and the Incubation Project on State Key Laboratory of Biological Resources and Ecological Environment of Qinba Areas (SLGPT2019KF04-04).

\section{Declarations}

\section{Competing interests}

The authors declare that they have no competing interests.

\section{Author details}

${ }^{1}$ Chinese-German Joint Laboratory for Natural Product Research, Key Laboratory of Biological Resources and Ecological Environment of Qinba Areas, School of Biological Science and Engineering, Shaanxi University of Technology, Hanzhong, China. ${ }^{2}$ Centre of Molecular and Environmental Biology, University of Minho, Campus de Gualtar, 4710-057 Braga, Portugal. ${ }^{3}$ Department of Biomedical Sciences, Ontario Veterinary College, University of Guelph, Guelph, ON, Canada. ${ }^{4}$ State Key Laboratory for Sheep Genetic Improvement and Healthy Production, Xinjiang Academy of Agricultural and Reclamation Science, Shihezi, China.

Received: 24 January 2021 Accepted: 2 May 2021

Published online: 13 May 2021

\section{References}

1. Zhang XY, Chen H, Tian Z, Chen S, Schade R (2010) Chicken monoclonal IgY antibody: a novel antibody development strategy. Avian Biol Res 3:97-106

2. Lee W, Syed Atif A, Tan SC, Leow CH (2017) Insights into the chicken IgY with emphasis on the generation and applications of chicken recombinant monoclonal antibodies. J Immunol Methods 447:71-85

3. Li C, He J, Ren H, Zhang X, Du E, Li X (2016) Preparation of a chicken scFv to analyze gentamicin residue in animal derived food products. Anal Chem 88:4092-4098

4. Ge S, Xu L, Li B, Zhong F, Liu X, Zhang X (2020) Canine Parvovirus is diagnosed and neutralized by chicken IgY-scFv generated against the virus capsid protein. Vet Res 51:110

5. Baloch AR, Baloch AW, Sutton BJ, Zhang X (2016) Antibody mimetics: promising complementary agents to animal-sourced antibodies. Crit Rev Biotechnol 36:268-275

6. Qiu XQ, Wang H, Cai B, Wang LL, Yue ST (2007) Small antibody mimetics comprising two complementarity-determining regions and a framework region for tumor targeting. Nat Biotechnol 25:921-929 
7. Ryvkin A, Ashkenazy H, Weiss-Ottolenghi Y, Piller C, Pupko T, Gershoni JM (2018) Phage display peptide libraries: deviations from randomness and correctives. Nucleic Acids Res 46:e52

8. Hoogenboom HR (2005) Selecting and screening recombinant antibody libraries. Nat Biotechnol 23:1105-1116

9. Borg NA, Ely LK, Beddoe T, Macdonald WA, Reid HH, Clements CS, Purcell AW, Kjer-Nielsen L, Miles JJ, Burrows SR, McCluskey J, Rossjohn J (2005) The CDR3 regions of an immunodominant T cell receptor dictate the'energetic landscape' of peptide-MHC recognition. Nat Immuno 6:171-180
10. Holliger P, Hudson PJ (2005) Engineered antibody fragments and the rise of single domains. Nat Biotechnol 23:1126-1136

11. Heap CJ, Wang Y, Pinheiro TJT, Reading SA, Jennings KR, Dimmock NJ (2005) Analysis of a 17-amino acid residue, virus-neutralizing microantibody. J Gen Virol 86:1791-1800

\section{Publisher's Note}

Springer Nature remains neutral with regard to jurisdictional claims in published maps and institutional affiliations.
Ready to submit your research? Choose BMC and benefit from:

- fast, convenient online submission

- thorough peer review by experienced researchers in your field

- rapid publication on acceptance

- support for research data, including large and complex data types

- gold Open Access which fosters wider collaboration and increased citations

- maximum visibility for your research: over $100 \mathrm{M}$ website views per year

At BMC, research is always in progress.

Learn more biomedcentral.com/submissions 